\title{
Education for Ethnic-racial Relations in the New Curriculum Guidelines and in the Common National Base for the Initial Training of Brazilian Teachers: Implications for the Teaching of Anti-racist Science and Biology
}

\author{
Joaklebio Alves da Silva*, Monica Lopes Folena Araújo \\ Post-Graduate Program in the Teaching of Science, Federal Rural University of Pernambuco, Recife, Pernambuco, Brazil \\ *Corresponding Author: joaklebio.silva@gmail.com
}

\section{ABSTRACT}

By ethnic-racial relations one understands the relations established between ethnic groups whose base is guided by race category, seen on a social perspective. Schools should be an environment propitious to the promotion of Education for Ethnic-racial Relations, the teacher being an indispensable agent in this process. The present study is characterized as documentary research with a qualitative approach that sought to analyze, in a comparative perspective, evidence of a proposal for Education for Ethnic-racial Relations present and/or absent in the Curriculum Guidelines and in the Common National Base for Initial Teacher Training (Resolution 2/2019), as well as the possible implications for the teaching of anti-racist Science and Biology in Brazil. The study leads us to conclude that the new Curricular Guidelines and the Common National Base for the Initial Teacher Training do not bring concrete evidence of an effective proposal for Education for Ethnic-Racial Relations as proposed by Resolution 2/2015, which was hastily revoked by Resolution 2/2019. The absence of these indications tends to result in negative implications for the teaching of anti-racist Science and Biology, since it was previously supported, we had found in the guidelines for teacher training an alternative to insert the study of ethnic-racial relations in undergraduate courses in the area. We hope that this study will collaborate for research in the area of teacher training and ethnic-racial relations in the teaching of science and biology, especially for educational policies aimed at training teachers.

KEY WORDS: Initial teacher training; education for ethnic-racial relations; national curriculum guidelines; national common base; science and biology teaching

\section{INTRODUCTION AND LITERATURE REVIEW}

\section{Education for Ethnic-racial Relations in the Initial Training} of Science and Biology Teachers in Brazil

T The training of teaching professionals for basic education has been configured as a field of dispute that involves dynamic, political, and curricular concepts (Dourado, 2015). The social, political, and economic changes that impact teaching practices in schools require certain adaptations in the formative process of teachers, due to the demands of the area that ends up reflecting in the curricular structure of the initial training courses and in continuous training.

It is important to note that teacher training in Brazil is guided by documents that have guidelines with a curriculum bias that underlie training proposals, within the scope of educational policies in Higher Education Institutions (HEIs) that offer undergraduate courses in different areas of knowledge. These courses need to meet a set of legislation that comes, for example, from discussions by social groups such as the Social Black Movement, with the struggle to insert African and Afro-Brazilian History and Culture in schools.
On the struggle of the Social Black Movement in Brazil, we bring the thoughts of (Gomes, 2017) when she states that this movement has gained a place of affirmative existence in the country from the moment that it brought the debate of racism into the public context and began to question public policies, including that of teacher training, about their role in overcoming racial inequalities. (Gomes, 2017) also complements the speech by recalling that Law 10,639/2003 was sanctioned in 2003, amending the Law of Guidelines and Bases of Brazilian Education (LDB), making the teaching of Afro-Brazilian and African History and Culture mandatory in the public and private education network of the country. 5 years later, Law 11,645/2008 was approved, amending Law 10,639/2003, including Indigenous History and Culture (Brasil, 2008).

As an unfolding result of Law 10,639/2003, in 2004, the Resolution of the National Education Council (CNE) was published: Full Council (CP) No. 01, of June 17, instituting the National Curriculum Guidelines for the Education of Ethnic-Racial Relations and for the Teaching of Afro-Brazilian and African History and Culture which also yields guidelines 
for the insertion of the theme in the teacher training curricula (Brasil, 2004).

We corroborate the concept of Ethnic-Racial Relations presented by (Verrangia and Silva, 2010), when they say that these are relationships established between different social groups and the people who compose them, based on concepts and ideas about the differences and similarities regarding belonging racial behavior of individuals and, consequently, of the group to which they belong. The objective of Education for Ethnic-Racial Relations, according to Professor and Doctor Petronilha Beatriz Gonçalves e Silva (2007) is to form "citizens, women and men, committed to promoting conditions of equality in the exercise of social, political, economic rights, of the rights to being, living, thinking, proper to the different ethnic-racial and social belongings" (p. 490).

Studies on Education for Ethnic-Racial Relations need to permeate all Basic Education, and this also depends on the training of teachers in HEIs. In turn, teacher training courses seek to comply with what is laid down in the legislation, especially that of a curricular character. We consider this a pertinent opportunity for the encouragement of guidelines that characterize a proposal for Education for Ethnic-Racial Relations in all areas of knowledge, including the Biological Sciences, which are present in the school through the teaching of Sciences and Biology.

Until the year 2019, the National Curriculum Guidelines for Initial and Continuing Education at Higher Level for Basic Education Teaching Professionals, was in force through Resolution No. 2/2015 (Brasil, 2015). It guaranteed the approach to ethnic-racial education in Brazil, as found in a previous study (Silva and Araújo, 2020).

In December 2019, a new Resolution No. 2 of the Ministry of Education, $\mathrm{CNE} / \mathrm{CP}$ was approved, which defined the National Curriculum Guidelines for the Initial Training of Teachers for Basic Education and instituted the Common National Base for the Initial Training of Teachers of Education. Basic (BNC- Training). This document appears to revoke Resolution $2 / 2015$, bringing changes in the fundamentals, objectives, contents, and in the training project that implies the curricular structure of the initial training of teachers; and this new Resolution established a period of 2-3 years for HEIs to adapt teacher training courses through the professional skills provided for in the document.

Considering that the new guidelines and common national base start to guide the courses of initial teacher training in Brazil, among them, those of Biological Sciences; and considering that the teacher training guidelines put in place through Resolution 2/2015 ensured an approach to Education for Ethnic-Racial Relations in teacher training; we seek to analyze with this study, in a comparative perspective, evidence of a proposal for Education for Ethnic-Racial Relations present and/or absent in the new Curricular Guidelines and in the Common National Base for initial teacher education, as well as the possible implications for teaching anti-racist science and biology in Brazil.

According to (Araújo, 2015), "society is requiring professionals capable of working in teaching who face tensions in the field of teaching work, what requires knowledge combined with professional commitment, which is also social" (p. 101). The school as the teacher's field of work is a space for strained social relations where we need to promote an educational process for ethnic-racial relations, which demands knowledge from the teacher.

We soon understood that the curriculum of teacher training courses needed to address cultural diversity, in particular, ethnic-racial diversity. In this point of view, we agree with the statement of (Barzano and Melo, 2019), when they highlight the urgency of "(de)building the curriculum of the teaching of Biology, from school to university, enabling new epistemological and methodological approaches, starting from the promotion of discussion and visibility to voices of resistance that, in most cases, are sujugates" (p. 205).

The deconstruction of the curriculum in this perspective implies the possibility of providing an anti-racist education in the teaching of Science and Biology. According to (Gomes, 2012), the structural change proposed by Law 10,639/2003 in Brazil opens possibilities for the construction of an anti-racist education that results in an epistemological and curricular rupture from the moment when it makes public and legitimizes the speech based on the intercultural dialog among knowledges, the Afro-Brazilian and African issue in education. Thus, we stress once again the importance of initial teacher training courses to consider studies related to Education for Ethnic-Racial Relations in their curricula.

\section{METHODOLOGY}

\section{Research Approach and Technique}

The study in question was developed in the light of the qualitative research approach. Indirect documentation was the technique used to collect the data because it refers to the stage in which the objective was to collect previous information about the field of interest of the study (Marconi and Lakatos, 2003), which in this case, is the initial training of Science and Biology teachers regarding Education for Ethnic-Racial Relations.

The survey took place in two complementary ways: The first consisted of documentary research, as a primary source, since the data collection was through a document in the public archive of the Brazilian Ministry of Education. The type of the document, in accordance with (Marconi and Lakatos, 2003), is characterized as an official written because it deals with Resolution CNE/CP No. 2/2019 that defines the National Curriculum Guidelines and the Common National Base for the Initial Teacher Training for Basic Education. The second is characterized as bibliographic research, as a secondary source, because we use bibliographic references of the printed type 
and publications related to the object of study for its theoretical basis (Marconi and Lakatos, 2003).

\section{Analysis of the Data}

The data analysis was guided by elements of the Content Analysis proposed by (Bardin, 1977) with regard to the pre-analysis of the material under study and the treatment of the results through the extraction, description, interpretation, and inference of excerpts from the Resolution 2/2019.

The pre-analysis started from the researchers' intuitions, as they identified that the initial teacher training courses in Brazil were guided by documents that support the curricula, what led them to choose the resolution to be analyzed. The exploration of the material also makes up the analysis stage and was carried out through reading the material to obtain impressions, such as terms related to issues of cultural/ethnic-racial diversity, in the document.

The treatment of the results was only possible after the reading that allowed the extraction of excerpts from the document which bring characteristics that configure the presence and/or absence of an educational process in face of the ethnic-racial relations for the initial teacher training. Consequently, interpretations about the excerpts extracted were made, so that it was possible to infer from the confrontation among bibliographic references bringing meaning and sense to the results.

\section{RESULTS AND DISCUSSION}

The National Curriculum Guidelines for Higher Education Initial Training of Teachers for Basic Education is structured in nine chapters. In addition to these chapters, the document also includes the Common National Base for the Initial Training of Teachers of Basic Education, named as BNCTraining. It is structured into ten general competencies similar to the Common Curricular National Base (BNCC) of Basic Education, and has specific competencies organized in three dimensions: The Professional Knowledge dimension, Professional Practice dimension, and Professional Engagement dimension. For each dimension, four specific competencies were put in place and, subsequently, skills were established to achieve those competencies.

It is worth noting that the 2015 guidelines already mentioned the need for a National Common Base for teacher training; however, it is not out of this need that BNC-Training originates. According to the statement by (Rodrigues et al., 2020), the proposal for the creation of the BNC - Teacher Training mentions that the referred document will seek to comply with the provisions of the educational legislation; nevertheless, the LDB points out that it is necessary to have a common national base for primary and secondary education; the National Education Plan also mentions a common national base for basic education curricula, which became the BNCC only in 2017 (Rodrigues et al., 2020). Thus, the authors point out that:
The movement to justify a document based on artificially placed legal demands and which erases the curricular histories built so far, makes the justification based on legal imperatives for the existence of the base very fragile. In addition, there is the intention to approve and implement the document in a vertical manner, without dialog, participation or discussion with the educational and academic community. (Rodrigues et al., 2020, p. 7).

Likewise, Dourado, rapporteur of Ruling CNE/CP No. 02/2015, states that the 2015 guidelines were directed toward the initial and continuing training of teachers as a definition of a common national base to articulate with the specific training dynamics of each HEI from their teacher training projects, based on a concept of emancipatory and permanent education and by the recognition of specificities:

...Of teaching work, which leads to the praxis as an expression of the articulation between theory and practice and as well as to the demand that the reality of the environments of the educational institutions of basic education and of the profession be taken into account. (Dourado, 2015, p. 307).

The basic conception laid down in the guidelines of 2015 seeks to be effective with basis on the guarantee of a broad process for the training of teachers considering curriculum diversification, without turning the training proposal into a project that reduces education to teaching only (Dourado, 2013). What we see in the BNC-Initial Training is the configuration of a common national base anchored in competencies and skills for the training of teachers, something never seen in this formative context. Structuring the training of teachers to fulfill competencies and skills is to want to minimize the formative dynamics in an attempt to direct it to merely reduced and uncritical learning.

Recently, we have realized that the BNCC of basic education has become a reference in discussions, even in the field of teacher training. When carrying out a critical-comparative reading between the guidelines of 2015 and those of 2019, (Bazzo and Scheibe, 2019) affirm that:

The BNCC, therefore, determined by the global agenda of maintaining capitalism, started to lead and dominate the discussions and debate regarding the training of teachers for basic education. The teacher was to be trained to meet the dictates of this curricular basis, which, as it is known, had a process that was substantially controversial in discussions by educators in the various entities, since its approval happened to meet a standard curriculum model for the whole country, elaborated according to a technicist/instrumental vision, favorable to the orientations of business groups, interested in training a worker who would be submissive to them, starting from, therefore, a curriculum close to what we could call minimal and very distant from a curriculum base that would provide them training capable of developing its autonomy and criticality. (p. 673). 
By guiding a training whose curriculum basis is far from providing a process that awakens in the teacher his autonomy and criticality, that document ends up impacting the proposal that involves ethnic-racial relations, previously assured by the guidelines of 2015. Siqueira et al., (2020) leads us to reflect on the issue when they mention that there is a logic that is established in the teacher education management process in Brazil, guided by actors linked to the business sector and focused on pragmatic bases aiming at and operationalizing a curriculum lacking in critical thinking, participation, and production of significant knowledge. The authors also state that if this process materializes in the training of teachers, it will directly affect the teaching work and its autonomy.

In the 2015 document, the discussion that guides the training courses for education professionals focused on Education for Ethnic-Racial Relations is brought about through ethnicracial diversity (Silva and Araújo, 2020). This diversity needs to permeate the entire curriculum considering the formative premise, the formative principle, the training project, the profile of the graduate, and the curricular structure of the courses.

As for the object of Resolution 2/2019, ethnic-racial diversity is not considered essential learning. In its article, it is proposed that the training presupposes the development, on the part of the undergraduate student, based on the ten competencies proposed by BNCC - Basic Education "as well as the essential learning to be guaranteed to the students, regarding intellectual, physical, cultural, social and emotional aspects of their education, with a view to the full development of people, aiming at Integral Education" (Brasil, 2019a, p. 2).

Despite mentioning the cultural and social aspects, this document does not meet the real needs of teacher training with regard to ethnic-racial diversity as guaranteed by Resolution 2/2015. The National Association of Graduate Studies and Research in Education-ANPEd, claims that the text of the new guidelines considers only an orientation and possibility for teacher training that is only underlying the BNCC.

When presenting the fundamentals for teacher training, it is claimed that the inclusion of knowledge produced by the sciences for the educational field "contributes to the understanding of the teaching-learning processes, and the pedagogical strategies and resources should be adopted, grounded in them, that favor the development of knowledge and eliminate barriers to accessing knowledge" (Brasil, 2019a, p. 3).

The teaching of Afro-Brazilian, African and Indigenous History and Culture has always been a point of discussion for its insertion in basic education, and one of the reasons is the problem of teacher-training that is characterized by the speech of teachers who claim to have no contact with studies related to the theme, what ends up reflecting on the pedagogical practices that consider the knowledge produced by the black and indigenous population for society. When this knowledge is absent since the initial teacher training, public policy for teacher training will not be contributing to the elimination of barriers to access to knowledge; on the contrary, it will be increasing them.

An example of this is found in the research of (Silva and Ramos, 2020) with Sciences teachers of the Quilombola School System, where they diagnosed that the said teachers had had no contact with ethnic-racial relations studies in their initial training, nor in continuing education courses, which implied the absence of contextualization of traditional quilombola knowledge in their pedagogical practices in science classes.

The analyzed document also determines principles for the curricular organization of higher education courses for teacher training, among them is the "adoption of an intercultural perspective of valuing national history, culture and arts, as well as the contributions of the ethnic groups that constitute nationality Brazilian" (Brasil, 2019a, p. 5). According to (Candau, 2011), the intercultural perspective favors the dialogue between different knowledges and knowledge, which is not evident in the new Resolution of 2019 with dubious discourse in other moments of the document, considering that the intercultural perspective requires a change of optics whose starting point, when seen in the context of pedagogical practices, needs to recognize the differences between the groups that make up Brazilian society.

Brazil is a multicultural country, that is, a country made up of multiple cultures that need to dialogue with each other through an intercultural perspective. For Kabengele Munanga, an anthropologist and Brazilian-Congolese professor, multiculturalism must be in search of establishing communication and integration between different cultures, including those that are not recognized in the shaping of citizenship (Munanga, 2015), such as the case of African and Afro-Brazilian culture, which was placed outside the curricula, making it necessary to make her insertion in schools and in the training of teachers.

Subsequently, Article 8 brings the pedagogical foundations for undergraduate courses as an axis of the curricular organization. Paragraph VIII states that the initial training of teachers for basic education must have the following, "Commitment to the integral education of teachers in training, aiming at the constitution of knowledge, competencies, skills, values and forms of conduct that respect and value diversity, human rights, democracy, and the plurality of ideas and concepts pedagogical" (Brasil, 2019a, p. 5).

It is worth noting that once again ethnic-racial diversity is not mentioned directly such as it was prioritized in the repealed guidelines. During Chapter III, which deals with the organization of the curricula of higher education courses for teachers, there are no subsidies that guide HEIs to structure undergraduate courses that seek to train teachers capable of identifying and considering diversity in the school environment, which hurts the commitment to promote comprehensive education for undergraduates and, consequently, for basic education students. 
Among the twenty pages of Resolution 2/2019, in just one moment when talking about the workload of undergraduate courses, is it advised that among the $800 \mathrm{~h}$ destined to the study of scientific, educational, and pedagogical knowledge (called Group I), they must be treated the thematic "Curriculum and its legal frameworks" bringing the "LDB, and art. 26-A," (Brasil, 2019a, p. 6) but that through the integration of the dimensions of professional competencies as organizers of the teacher training curriculum under the aegis of the competencies and skills of the BNCC of basic education for all its stages (Brasil, 2019a). Indirectly, the Resolution camouflages Law $10,639 / 2003$ and ends up mentioning, basically enforced, Article 26-A of the LDB, which has the obligation to teach Afro-Brazilian History and Culture.

In support of the defense of Santos and Coelho (2015), we share the affirmation of the authors since they infer that Law $10,639 / 2003$ contributes to the inclusion of racial issues and human rights within the scope of Brazilian curriculum policy, "being one of the mechanisms to contest the absence of Afro-Brazilian history and culture in the school curriculum, Pedagogical Political Project, teaching plans and the "racial" inequalities introduced in the imagery of the Basic School" (p. 117). Leaving it out of a guideline responsible for guiding the curricular structuring of teacher training courses in Brazilian HEIs, is a reaffirmation of the political attempt to backtrack education in face of the progress that it has been having in recent years with regard to the discussions that consider Education for Ethnic-Racial Relations in teacher training and practice, especially in the Biological Sciences Teaching courses, which has shown its formative fragility with the absence of studies of Afro-Brazilian and African history and culture.

Still regarding degree courses, when they present $1600 \mathrm{~h}$ destined for the learning of contents of the several specific areas, of components, thematic units and objects of knowledge in accordance with the provisions of the BNCC (called Group II) "and for the pedagogical domain of these contents" (Brasil, 2019a, p. 6), article 13 paragraph 1 presents some skills that should be considered during the aforementioned workload in the training of teachers. Among them are:

IX- exchange between the contents of the areas and the components of the BNC- Training with the political foundations referring to equity, equality and understanding of the teacher's commitment to the content to be learned; and X- engagement with their training and professional development, participation and commitment to the school, with interpersonal, social and emotional relationships. (Brasil, 2019a, p. 8).

The curricular structure of undergraduate courses marked by Resolution 2/2015 guaranteed the contents related to ethnic-racial diversity in the initial training of teachers, in the pedagogical training of non-graduates and in second-degree courses. The training project contained in the same resolution brought issues related to ethnic-racial diversity as a principle of equity, a fact that is absent in Resolution 2/2019, even in the face of the requirement for the courses to promote the articulation between the areas of BNC-Initial Training with the fundamentals that refer to equity and equality. For the teacher to be committed to interpersonal and social relationships, the curriculum also needs to base his/her training so as to offer him or her the necessary knowledge for educational practice regarding ethnic-racial relationships that are immersed in social and interpersonal relationships.

We agree with (Bazzo and Scheibe, 2019) when they say that we need to publicly fight this document, as it is evident that its assumptions mischaracterize the training of teachers that the representative entities have been defending for years, including the Black Social Movement that claims for the inclusion of the ethnic-racial theme in teacher education. According to the authors, this legislation is based on principles incompatible with what is proposed in Resolution 2/2015, even when it is clear that part of the educational legislation is not effectively enforced, as in the case of Laws 10,639/2003 (Brasil, 2003) and 11,645/2008 (Brasil, 2008).

In line with the BNCC's ten general competencies in basic education, the document includes an annex to BNC- Initial Training, presenting ten general teaching competencies for initial teacher training. Among the competencies, only two (number 1 and 9) will be highlighted below according to the order in which they appear in the document:

1- Understand and use the knowledge historically constructed to be able to teach reality with engagement in student learning and in their own learning, collaborating for the construction of a free, fair, democratic, and inclusive society. 9- Exercise empathy, dialog, conflict resolution and cooperation, ensuring respect and promoting respect for others and human rights, with acceptance and appreciation of the diversity of individuals and social groups, their knowledge, identities, cultures and potentialities, without prejudice of any kind, to promote a collaborative environment in learning places. (Brasil, 2019a, p. 13).

The attempts to align teacher training with the BNCC of basic education is increasingly evident, one of which is the establishment of a Pedagogy of Skills that implies new standards of cognition, sociability, and citizenship (Siqueira et al., 2020). Mello (2018) reports on the demand for a new cognitive and social profile of the globalized economy and citizenship and points out that these demands "have been driving educational reforms that have two more important aspects: What should be learned and taught, and how learning should be assessed, considering schooling no longer of minorities, but of large population masses" (p. 69).

This demand, as explained by (Mello, 2018), ends up restricting teacher training and this leads the training process to prioritize disconnected social demands with the commitment to educate for citizenship and critical action in society, which results in the elimination of relevant discussions for the training of education professionals. For example, we deal with ethnic- 
racial diversity as the foundation of a proposal for Education for Ethnic-Racial Relations based on Afro-Brazilian, African and Indigenous History and Culture.

Unlike the 2015 Resolution, knowledge such as that historically constructed by the black population, will not be included in the competencies provided in the BNC- Initial Formation, since Afro-Brazilian and African History and Culture is basically excluded and/or fabricates during the approved guidelines in 2019. Consequently, respect for others and the appreciation of ethnic-racial diversity, represented indirectly by what they call "diversity of individuals and social groups" (Brasil, 2019a, p. 13), will be placed outside the curriculum of initial teacher training courses. This action will end up causing the increase and enrooting of racial prejudice and discrimination in Brazil, which affects the education of ethnic-racial relations.

Almeida (2020) tells us what prejudice and racial discrimination are, the first term being "the judgment based on stereotypes about individuals who belong to a certain racialized group, and which may or may not result in discriminatory practices;" and the second, "assigning different treatment to members of racially identified groups" (p. 32).

Furthering discussion on the basis, the specific skills of BNC- Initial Training refer to three dimensions considered as fundamental, namely, Professional Knowledge, Professional Practice and Professional Engagement. Only in the Professional Engagement dimension do we have a specific competence that contains a skill related to ethnic-racial issues. The competence consists of "committing to the students' learning and putting into practice the principle that everyone is capable of learning" (Brasil, 2019a, p. 19). The skill is "to pay attention to the different forms of physical and symbolic violence, as well as the ethnic-racial discrimination practiced in schools and in digital environments, in addition to promoting the ethical, safe, and responsible use of digital technologies" (Brasil, 2019a, p. 19).

In a way, the ability to learn mentioned in the Professional Engagement competence does not guarantee, for example, that black students will have access to the knowledge constructed by the black population in a way that they feel represented, according to the mandatory nature ensured by Law $10,639 / 2003$. This becomes obvious when we look at BNCInitial Training looking for elements that configure a proposal for Education for Ethnic-Racial Relations in initial teacher training. How can teachers' pay attention to and intervene in the different forms of ethnic-racial discrimination practiced at school and in digital media if their training does not contribute to this? The guarantee of Education for Ethnic-Racial Relations is indispensable, especially in the initial training of teachers. It has been more than a decade and a half after the approval of the law that regulates the teaching of Afro-Brazilian History and Culture in schools and what seems to us is that teacher training is still triggering the promotion of training processes committed to this cause, even when we take the resolution under analysis as a basis.

We align ourselves with the defense of Rodrigues et al. (2020) when the authors state that:

It is important to understand that the new Resolution, first of all, supports the movement of aligning and narrowing the curriculum of teacher training to High School Reform (Law No. 13,415, 2017), to the BNCC for Early Childhood Education and Elementary Education (2017) and BNCC High School (2018), as well as giving another direction to what was being understood and built as Guidelines for the training of teachers in our country. (p. 34).

In fact, it is clear that the document in question tries to align teacher training with the recent curricular reforms in basic education, leaving out extremely important themes and that were and/or are being carried out in teacher training lately, as it is the case of studies of ethnic-racial relations in the training of science and biology teachers.

The document points to the attempt to impose, in the HEIs, a Common National Base for the Formation of Teachers that do not meet the specificities of training that will seek to educate ethnic-racial relations in basic education as a process of repairing history through the insertion of History and Afro-Brazilian and Indigenous Culture, according to Laws 10,639/2003 and 11,645/2008.

The teacher trained in the light of BNC-Initial Training will hardly have access to knowledge that makes them pay attention to and intervene critically in the various forms of ethnic-racial discrimination in school and in society. This will reinforce the growth of the excuse given by teachers when they are asked about the absence of work with pedagogical practices related to Education for Ethnic-Racial Relations: "I did not have access to this knowledge during my training."

One can see the setback contained in the new guidelines and in the BNC-Initial Training as we can see in Resolution 2/2019. The document excludes the guarantee of knowledge necessary for the initial training of teachers capable of leading education professionals to commit themselves to the values of an ethnic and racial society, mischaracterizing the social role of the school in terms of educating ethnic-racial relations. It is truly an attempt to divert teacher training from the path that guaranteed respect, appreciation, consideration, and recognition of the ethnic-racial diversity now proposed by Resolution 2/2015.

\section{Implications for the Teaching of Anti-racist Science and Biology}

We cannot deny the deepening of racism in Brazilian society, even if allowing for all the ethnic and cultural diversity of the country. Decoloniality theorists reiterate that racism is also an organizing principle for those who can formulate and disseminate reliable scientific knowledge and for those who cannot and who have their knowledge silenced (Bernardino-Costa et al., 2019). 
This implies the decolonization of curricula for teacher training courses, including those in the area of Science and Biology. Law 10,639/2003 has taken on a political and epistemological commitment thanks to the Black Social Movement, as explained by Gomes (2019). Gomes (2019) argues that this movement and its intellectuals brought to Humanities and Social Sciences: "The Brazilian decolonial black perspective, one of those responsible for the process of decolonization of curricula and knowledge in Brazil" (p. 223).

Springing from the understanding about the decolonization of curricula advocated by Gomes (2019), it is possible to affirm that this process takes place jointly with several contributions, among which are those arising from educational legislation, scientific research, and the efforts of those who share in another a different perspective from the universal reference standard with regard to pedagogical practices under the aegis of Afro-Brazilian and Indigenous History and Culture. When we make a cut for the areas of knowledge, it is undeniable that the Biological Sciences is still considered, by education professionals, as an area lacking potentiality for the development of an anti-racist work. The elucidation of the area in view of its potential to fill this formative gap arises with an emphasis on the obligation placed on educational legislation and on the effort of black intellectuals to bring the theme to the training of teachers and, consequently, to the teaching of Science and Biology in schools.

When faced with the absence of an approach that configures a proposal for Education for Ethnic-Racial Relations in the documents that guide the curricula of initial teacher training courses, as is the case with the guidelines and common national basis (Resolution 2/2019), we soon identify implications in this formative process when we report to the social role of the school in repairing history related to the aesthetic, intellectual, religious, social, and cultural positivity of black people in Brazilian society. The implications extend to the teaching of Sciences and Biology as a consequence of being an area whose collaboration for anti-racist teaching should be more effective, since the classification of human beings by races took place within the scope of racist theories when black people were classified and judged to a lower group through their appearance physics, feeding the concept of race through biological bias.

The work carried out in the context of teacher training is also a positive reflection of the guarantee of the ethnic-racial theme in the 2015 guidelines, given that they guided initial training courses and continuing teacher training in the country. In addition, the works are the result of the efforts of researchers in the various Brazilian HEIs based on the teaching, research and extension triad that contributes to the training and pedagogical practice of Science and Biology teachers.

Traces of the mismatch between the proposal of Resolution 2/2019 compared to what is demanded of the teacher in basic education are increasingly evident. Proof of this can be seen in the proposal of Contemporary Cross-cutting Themes at the BNCC of Basic Education (Brasil, 2019b) and that it hurts the teaching of anti-racist Science and Biology in Brazil, precisely because it does not find formative foundations in the new guidelines and common national basis.

Among the Cross-cutting Themes suggested for work in basic education and which reflect a possible proposal for Education for Ethnic-Racial Relations, are those present in some macro thematic areas, as it is called in the document, namely: Science and Technology, Environment, Health and Multiculturalism. The macro areas even appear to be a coherent proposition that could take as a reference the contributions of Brazilian researchers and teachers to the planning of pedagogical practices for the teaching of Sciences and Biology, but we will not find support from the initial training of teachers, since the courses are unlikely to be covered by an Education for EthnicRacial Relations process.

In proposing the discussion in the macro area science and technology, the curriculum could consider work that deals with the contribution of black people in the development of Science and Technology in the country, as presented by the professor and doctor in Chemistry Teaching Bárbara Carine Soares Pinheiro in her text "Science Education in the Democratic School and Ethnic-Racial Relations" (Educação em Ciências na Escola Democrática e as Relações ÉtnicoRaciais), which presents scientific productions of African people and in the diaspora (Pinheiro, 2019), as well as in his book“@Decolonizing_Knowledge: Black Women in Science" (@Descolonizando_Saberes: Mulheres Negras na Ciência) (Pinheiro, 2020).

Regarding the macro area Environment, it is possible to discuss environmental racism in science education as proposed in the master's thesis by Ingriddy Nathaly Santos Moreira (Moreira, 2020).

In the Health macro area, we have found opportunities to discuss the health of the black population in Brazil as provided by research conducted by the doctor in anthropology Ana Cláudia Rodrigues da Silva about the place of the race category in the approach to anemia/sickle cell disease in Brazil (Silva, 2014); and José Antonio Novaes da Silva, PhD in Biochemistry, with studies related to the practice of bleeding between Remetu-Kemi and people from the Congo/Angola region (Silva, 2017).

Multiculturalism is more of a macro area and proposes work with Cultural Diversity, Education for the valuation of multiculturalism in Brazilian historical and cultural matrices (Brasil, 2019b). We found contributions in the proposal prepared by (Verrangia, 2010), which brings the valorization of the African matrix in the teaching of Sciences through a set of suggestions that consider traditional Afro-Brazilian and African knowledge for the formation of teachers and Science classes as a way of effecting the Law 10,639/2003 to educate ethnic-racial relations in educational institutions.

According to the document, proposals can be drawn in one or more curricular components through the intradisciplinary, interdisciplinary or transdisciplinary approach, but always 
across the fields of knowledge (Brasil, 2019b). With this we want to demarcate from the moment that the initial teacher training courses guided by a decolonized curriculum proposal, different from Resolution 2/2019, discuss issues related to the ethnic-racial theme to the point of training capable and willing teachers to fight against racism through of their classes, the proposals presented above are closer to being put into practice in Science and Biology classes. For (Gomes, 2019), it is only possible to decolonize curricula and knowledge if we decolonize our look at the other, at the experiences of the other and on how the other produces knowledge. Therefore, understanding the existence of a black decolonial perspective in Brazil depends on the recognition of black people and their movements for emancipation.

It is notorious that there is a curricular dispute in the training of teachers (Dourado, 2015), and that can be seen in situations experienced by Brazilian education and by society as a whole, both through the decisions of the Executive, Legislative and Judiciary, as well as by the dynamics educational, religious and family institutions (Gomes, 2019). An example of this dispute is the colonial resistance to a decolonial curriculum by groups in Brazil that seek to change the LDB to include the (Escola sem Partido) Program, a retrograde program aimed at Brazilian education and the curriculum that fights to prevent freedom of thought and curricular and didactic-pedagogical autonomy present in educational institutions and their teachers (Gomes, 2019).

Dorvillé and Teixeira (2019) talk about the multiplier effect of teacher training when they argue about the consideration of Science and Biology teachers related to pedagogical practice when they believe that their function at school ends after the presentation of the specific contents of the area in the classroom, often the result of their initial training, which at times do not consider themes such as ethnic-racial diversity.

When the normative documents of the teacher education curriculum do not fulfill their role in educating ethnic-racial relations through knowledge that results in an anti-racist education, we may have "future Science and Biology teachers who are not able to recognize the relevance of teaching this knowledge to their students in a way that enhance their incorporation to their repertoire of interpretations of the world to some degree" (Dorvillé and Teixeira, 2019, p. 13).

Taking into account that the teacher training curriculum meets the guidelines of the national curriculum guidelines and, recently, the common national basis for initial teacher training, to what extent the curricula of undergraduate courses will consider such a need since these documents do not meet explicitly an effective approach to Education for Ethnic-Racial Relations? This is an issue that we leave for our reflection because we believe that the absence of this approach in the referred curricular documents will impact the structuring of the initial teacher training courses in Brazil, including those in Sciences and Biology, a fact that could be reversed if Resolution 2/2015 to come back into force.

\section{CONCLUSIONS}

The study allows us to conclude that the new Curricular Guidelines and the Common National Base for the initial training of teachers in Brazil, published by Resolution 2/2019, do not bring concrete evidence of an effective educational process aimed at Education for Ethnic-Racial Relations as well as brought by Resolution $2 / 2015$, which was hastily revoked by the new guidelines and common national base.

The absence of these indications tends to result in implications for the teaching of anti-racist Science and Biology, since previously we found support in the teacher training guidelines as another alternative to insert the study of ethnic-racial relations in the area's undergraduate courses. Research studies have pointed out that it is essential to include in the initial training of Science and Biology teachers the study of ethnic-racial relations, as found in the doctoral thesis of (Verrangia, 2009) as pioneering research in Brazil.

One cannot deny that the Teacher Training courses in Biological Sciences can consider discussions that contribute to the Education of Ethnic-Racial Relations without depending exclusively on the guidelines and common national basis for teacher training. However, it is impracticable not to bring up the absence of an effective approach in that document because it is the normative structure that guides teacher training courses in the country, which could not be left out of the discussion around Education for Ethnic-Racial Relations.

The demand for Science and Biology teaching to assume its educational and social commitment to educate ethnic-racial relations is increasingly evident, contributing to the anti-racist struggle in Brazil. Teacher training needs to be consolidated as a structuring basis for the implementation of practices committed to the ethnic-racial cause.

We hope that this study will collaborate for research in the area of teacher training and ethnic-racial relations in the teaching of Science and Biology, especially for educational policies aimed at training teachers in the care of themes that are sometimes excluded, placed on the margins and/or hidden from the initial training curricula and which ends up impacting school pedagogical practice.

\section{ACKNOWLEDGMENTS}

The authors would like to thank the Coordination for the Improvement of Higher Education Personnel for the scholarship granted.

\section{REFERENCES}

Almeida, S. (2020). Racismo Estrutural. [Structual Racism]. Editora Jandaíra. 
Araújo, M.L.F. (2015). A Educação Ambiental Crítico-Humanizadora na Formação de Professores de Biologia. [Critical-Humanizing Environmental Education in Biology Teacher Training]. Brazil: Editora UFPE.

Bardin, L. (1977). Análise de Conteúdo. [Contente Analysis]. Issues 70; ??? Barzano, M.A.L., \& Melo, A.C. (2019). Saberes da biodiversidade: Perspectivas decoloniais no currículo do ensino de biologia. [Biodiversity knowledge: Decolonial perspectives in the biology teaching curriculum]. Revista Teias, 20(59), 191-208.

Bazzo, V., \& Scheibe, L. (2019). De volta para o future ... retrocessos na atual política de formação docente. [Back to the future... setbacks in the current teacher education policy]. Revista Retratos da Escola, 13(27), 669-684.

Bernardino-Costa, J., Maldonato-Torres, N., \& Grosfoguel, R. (2019). Introdução: Decolonialidade e pensamento afrodiaspórico. [Introduction: Decoloniality and Aphrodiaspora thinking]. Em Bernardino-Costa, J., Maldonato- Torres, N., \& Grosfoguel, R., (Eds.), Decolonialidade e Pensamento Afrodiaspórico. [Decoloniality and Aphrodiaspora Thinking]. $2^{\text {nd }}$ ed. Brazil: Autêntica Editora. pp. 9-26.

Brasil. (2003). Lei No. 10, 639, de 9 de Janeiro de 2003. [Law No. 10, 639, of January 9, 2003]. Presidência da República, Casa Civil, Subchefia para Assuntos Jurídicos.

Brasil. (2004). Resolução CNE/CP No. 1, de 17 de Junho de 2004. [CNE/CP Resolution No. 1, of June 17, 2004]. Ministério da Educação, Conselho Nacional de Educação, Conselho Pleno.

Brasil. (2008). Lei No. 11, 645, de 10 de Março de 2008. [Law No. 11, 645, of March 10, 2008]. Presidência da República, Casa Civil, Subchefia Para Assuntos Jurídicos.

Brasil. (2015). Resolução CNE/CP No. 2, de 1 de Julho de 2015. [CNE/CP Resolution No. 2, of July 1, 2015]. Ministério da Educação, Conselho Nacional de Educação, Conselho Pleno.

Brasil. (2019a). Resolução CNE/CP No. 2, de 20 de Dezembro de 2019. [CNE/CP Resolution No. 2, of December 20, 2019]. Ministério da Educação, Conselho Nacional de Educação, Conselho Pleno.

Brasil. (2019b). Temas Contemporâneos Transversais na BNCC: Proposta de Práticas de Implementação. [Contemporary Cross-cutting Themes at BNCC: Proposal for Implementation Practices]. Ministério da Educação, Secretaria de Educação Básica, Diretoria de Políticas e Regulamentação da Educação Básica.

Candau, V.M.F. (2011). Diferenças culturais, cotidiano escolar e práticas pedagógicas. [Cultural differences, school routine and pedagogical practices]. Currículo sem Fronteiras, 11(2), 240-255.

Dorvillé, L.F., \& Teixeira, P.P. (2019). Ensino de Ciências e Biologia e a necessidade de uma ética cordial: Ensino de evolução, crenças religiosas e estratégias empáticas. [Teaching Science and Biology and the need for cordial ethinics: Teaching evolution, religious beliefs, and empathic strategies]. In: Teixeira, P.P., Oliveira, R.D.V., \& Queiroz, G.R.P., (Eds.), Conteúdos Cordiais: Biologia Humanizada Para Uma Escola Sem Mordaça. [Cordial Contents: Humanized Biology for a School without a Gag]. $1^{\text {st }}$ ed. Brazil: Editora Livraria da Física. pp. 1-16.

Dourado, L.F. (2013). A formação de professores e a base comum nacional: Questões e proposições para o debate. [Teacher training and the national common base: Questions and propositions for debate]. Revista Brasileira de Política e Administração da Educação, 29(2), 367-388.

Dourado, L.F. (2015). Diretrizes curriculares nacionais para a formação inicial e continuada dos profissionais do magistério da educação básica: Concepções e desafios. [National curriculum guidelines for the initial and continuing education of professionals in the teaching of basic education: Concepts and challenges]. Educação and Sociedade Campinas, 36(131), 299-324.

Gomes, N.L. (2012). Relações étnico-raciais, educação e descolonização dos currículos. [Ethnic-racial relations, education and curriculum descolonization]. Revista Currículo sem Fronteiras, 12(1), 98-109.

Gomes, N.L. (2017). O Movimento Negro educador: Saberes Construidos Nas Lutas Por Emancipação. [The Black Educator Movement: Knowledge Built on Struggles for Emancipation]. Vozes.

Gomes, N.L. (2019). O Movimento negro e a intelectualidade negra descolonizando os currículos. [The black movement and black intelligentsia decolonizing curricula]. In: Bernardino-Costa, J., Maldonato-Torres, N., \& Grosfoguel, R., (Eds.), Decolonialidade e Pensamento Afrodiaspórico. [Decoloniality and Aphrodiaspora Thinking]. $2^{\text {nd }}$ ed. Brazil: Autêntica Editora. pp. 223-246.

Marconi, M.A., \& Lakatos, E.M. (2003). Fundamentos de Metodologia Cientifica. [Fundamentals of Scientific Methodology]. $5^{\text {th }}$ ed. Atlas Editora.

Mello, G.N. (2018). Formação inicial e continuada de professores. [Initial and continuing teacher education]. In: Castro, M.H.G., \& Callou, R., (Eds.), Educação em Pauta: Uma Agenda Para o País. [Education on the Agenda: An Agenda for the Country]. Organização de Estados Iberoamericanos para a Educação, a Ciência e a Cultura.

Moreira, I.N.S. (2020). Racismo Ambiental Como Questão Bioética Para o Ensino de Ciências: Construção de Uma Proposta Colaborativa de Formação Inicial de Professores. [Environmental Racism as a Bioethical Issue for Science Teaching: Construction of a Collaborative Proposal for Initial Teacher Education]. Dissertação de Mestrado em Ensino de Ciências, Universidade Federal de Ouro Preto. [Master's thesis in Science Teaching, Federal University of Ouro Preto]. Ouro Preto. Repositório. Available from: https://www.repositorio.ufop. br/handle/123456789/12662

Munanga, K. (2015). Por que ensinar a história da África e do negro no Brasil de hoje? [Why teach the history of Africa and the black people in Brazil today?]. Revista do Instituto de Estudos Brasileiros, 62, 20-31.

Pinheiro, B.C.S. (2019). Educação em ciências na escola democrática e as relações étnico-raciais. [Science education in the democratic school and ethnic-racial relations]. Revista Brasileira de Pesquisa em Educação em Ciências, 19, 329-344.

Pinheiro, B.C.S. (2020). @Descolonizando-Saberes: Mulheres Negras na Ciência. [@Decolonizing-Knowledge: Black Women in Science]. Brazil: Editora Livraria da Física.

Rodrigues, L.Z., Pereira, B., \& Mohr, A. (2020). O documento "proposta para base nacional comum da formação de professores da educação básica" (BNCFP): Dez razões para temer e contestar a BNCFP. [The document "proposal for a common national basis for the training of basic education teachers" (BNCFP): Ten reasons to fear and contest the BNCFP]. Revista Brasileira de Pesquisa em Educação em Ciências, 20, $1-39$.

Santos, R.A., \& Coelho, W.N.B. (2015). Política Curricular e relações raciais no Brasil: Entre textos e discursos. [Curriculum Policy and race relations in Brazil: Between texts and discouses]. In: Coelho, W.N.B., Vale, J.C.C., Soares, N.J.B., \& França, R.C.C., (Eds.), Educação, História e Relações Raciais: Debates em Perspectiva. [Education, History and Race Relations: Debates in Perspective]. Brazil: Editora Livraria da Física. pp. 99-136.

Silva, A. C. R. (2014). Compartilhando Genes e Identidades: Orientação Genética, Raça e Políticas de Saúde Para Pessoas Com Doença e Traço Falciforme em Pernambuco. [Sharing Genes and Identities: Genetic Orientation, Race and Health Policies for People with Sickle Cell Trait and Disease in Pernambuco]. $1^{\text {st }}$ ed. Brazil: Editora Universitária UFPE.

Silva, J.A., \& Araújo, M.L.F. (2020). Abordagem das relações étnicoraciais nas diretrizes curriculares nacionais para a formação inicial e continuada em nível superior de profissionais do magistério para a educação básica. [Approach to ethnic-racial relations in the national curriculum guidelines for initial and continuing education at higher level of teaching professionals for basic education]. Revista Educação, Cultura e Sociedade, 10(3), 355-370.

Silva, J.A., \& Ramos, M.A. (2020). A contextualização de conhecimentos prévios/tradicionais de alunos quilombolas: O que dizem os professores de ciências? [The contextualization of previous/traditional knowledge of quilombola students: What do science teachers say?]. Góndola, Enseñanza y Aprendizaje de las Ciencias, 15(1), 152-170.

Silva, J.A.N. (2017). Conquista de direitos, ensino de Ciências/Biologia e a prática da sangria entre os/as remetu-kemi e povos da região Congo/ Angola: Uma proposta de articulação para a sala de aula. [Conquering rights, teaching science/biology and the practice of bloodletting among the Remetu-Kemi and peoples of the Congo/Angola region: A proposal of articulation for the classroom]. Revista da Associação de Pesquisadores/as Negros/as, 9(22), 149-175.

Silva, P.B.G. (2007). Aprender, ensinar e relações étnico-raciais no Brasil [Learning teaching and ethnic-racial relations in Brazil]. Educação, 3(63), 489-506. 
Siqueira, R.M., Dourado, L.F., \& Aguiar, M.A.S. (2020). Plano nacional de educação, base nacional comum curricular e a formação de professores: A autonomia docente em questão. [National education plan, common national curriculum base and teacher training: Teacher autonomy in question]. In: Dourado, L.F., (Ed.), PNE, Políticas e Gestão da Educação: Novas Formas de Organização e Privatização. [PNE, Education Policies and Management: New Forms of Organization and Privatization]. Anpae.

Verrangia, D. (2009). A Educação das Relações Étnico-Raciais no Ensino de Ciências: Diálogos Possíveis Entre Brasil e Estados Unidos. [The Education of Ethnic-Racial Relations in Science Teaching: Possible Dialogues between Brazil and the United States]. Tese de
Doutorado em Educação, Universidade Federal de São Carlos. [PhD Thesis in Education, Federal University of São Carlos]. São Carlos, Repositório. Available from: https://www.repositorio.ufscar.br/handle/ ufscar/2222?show=full

Verrangia, D. (2010). Conhecimentos tradicionais de matriz africana afro-brasileira no ensino de Ciências: Um grande desafio. [Traditional knowledge of African and Afro-Brazilian matrix in Science teaching: A great challeng]. Revista África e Africanidades, 2(8), 1-14.

Verrangia, D., \& Silva, P.B.G. (2010). Cidadania, relações étnicoraciais e educação: Desafios e potencialidades do ensino de ciências. [Citizenship, ethnic-racial relations and education: Challenges and potential of science teaching]. Educação e Pesquisa, 36(3), 705-718. 